\title{
Urban Green Space and Urban Biodiversity: Kuala Lumpur, Malaysia
}

\author{
Sadasivam Karuppannan ${ }^{1}$, Zainul Mukrim Baharuddin ${ }^{2}$, Alpana Sivam ${ }^{1} \&$ Chris B. Daniels ${ }^{3}$ \\ ${ }^{1}$ Barbara Hardy Institute and School of Natural and Built Environments, University of South Australia, Adelaide, \\ Australia \\ ${ }^{2}$ International Islamic University Malaysia, Kuala Lumpur, Malaysia \\ ${ }^{3}$ Barbara Hardy Institute, University of South Australia, Adelaide, Australia \\ Correspondence: Sadasivam Karuppannan, Barbara Hardy Institute and School of Natural and Built \\ Environments, University of South Australia, GPO Box 2471, Adelaide, SA 5001, Australia. Tel: \\ 61-883-021-066. E-mail: Sadasivam.Karuppannan@unisa.edu.au
}

Received: October 8, $2013 \quad$ Accepted: November 27, $2013 \quad$ Online Published: December 19, 2013
$\begin{aligned} & \text { doi:10.5539/jsd.v7n1p1 } \\ & \text { URL: http://dx.doi.org/10.5539/jsd.v7n1p1 }\end{aligned}$

\begin{abstract}
Urban green space plays an important role in enhancing the quality of environment especially for urban biodiversity. Declining biodiversity around the world has received much attention among academics, professionals and citizens. The United Nations has declared year 2010 as the 'International Year of Biodiversity'. Urban biodiversity movement is important to ensure healthy city environments. Despite this ongoing movement, urban dwellers have little knowledge about conservation of biodiversity particularly wildlife. Moreover, biodiversity has received little attention from built environment practices (Brown \& Grant, 2005; Niemelä, 1999).

In general, urban wildlife habitat is protected as reserved forest. Many species of wildlife are generally found in such reserved forests. In comparison, the scale of urban parks in Kuala Lumpur is massive, much larger than protected forests. This paper presents the situation of urban wildlife species and the quality of habitats in Kuala Lumpur. It is found that many factors contribute to the healthy conservation of urban wildlife such as quality and variety of habitats, ornamental versus native vegetation and ecological design. The findings highlight that common urban birds are dominant in urban green spaces regardless of the size of the green spaces. However, only larger urban green spaces help protect species. Finally, the study concludes that urban wildlife in Kuala Lumpur is rapidly declining and that there is a greater need for the community and stakeholders to promote programs and activities to preserve and enhance urban wildlife. Development of comprehensive acts, policies and guidelines are vital for urban wildlife protection.
\end{abstract}

Keywords: urban wildlife, ecological design, wildlife management, urban green space, conservation

\section{Introduction}

There is strong relationship between green open space, peoples' mental and physical wellbeing and presence of biodiversity and wildlife habitats within established built environments. Biodiversity refer to all living things, from the largest species down to the smallest micro-organisms. Rapid urbanisation has threatened the natural habitats for plants and animals, resulting in the loss and elimination of some species and habitats.

Rapidly increasing rates of urbanization in developing countries has resulted in considerable reduction in green open space because of pressure for provision of housing and related essential infrastructure. This has underlined a need for protection and preservation of green open spaces. Some developing countries did not learn from others which have lost their natural resources, native vegetation and exotic wildlife species. This is due to lack of appropriate environmental management and accountability from the government or lack of expertise and knowledge (Baharuddin et al., 2009).

Rising urban populations mean increase in the demand for urban parks and green spaces. Good quality urban parks and green spaces need to be conceived as outdoor room within a neighborhood, somewhere to relax and enjoy the urban experience; a venue for a range of varies activities such as passive and active recreation. Thus, peoples' demands for more sustainable planning and development should occur in cities where they can live in 
comfort, safety and enjoyment. On the other hand the urban biodiversity (fauna \& flora) should be enhanced to conserve and manage appropriately in order to maintain ecological benefits.

Loss of habitats such as in the conservation of Panthera tigris (Sumatra Tiger) in Malaysia have received worldwide attention. In the last 30 years, forest cover in Malaysia has declined by $19.3 \%$ and the land has been converted to agriculture mainly for rubber and palm oil plantations (Ministry of Science, 1998). Physical development activities in the future will affect about 300 species of wild mammals, 750 species of birds, 350 species of reptiles, 165 species of amphibian and others including invertebrates and microorganisms (Ministry of Science, 1998).

The United Nations has declared 2010 as the "International Year of Biodiversity". The biodiversity movement will initiate many activities such as conferences and debates on world biodiversity (UN, 2010). This movement promoted fresh commitments since the United Nations Conference on Environment and Development at Rio de Janeiro in 1992. Malaysia has been strengthening conservation policies through the Convention on Biological Diversity 1994 with visions to operate national policy over the conservation programs (Ministry of Science, 1998).

Despite the focus on mega fauna, there is less concern and effective management in relation to less popular wildlife species especially in urban areas. There is little research on the impact and relationship between urbanization and urban wildlife. Thus it is important to understand the human ecosystem in relation to urban vegetation and urban wildlife. Urban wildlife has adapted in new environments through the urbanization process. Despite decreasing species richness, urban wildlife has somehow increased and is homogeneous in species-dominated urban spaces (Loss et al., 2009; McKinney, 2008; Chace \& Walsh, 2006; Savard et al., 2000).

Species richness and density can be associated with the quality of urban environment. There are many studies that have studied birds as a biological indicator. Most of the studies reflected that urban centres record lower species richness and this increases from suburban areas through to agricultural, rural and natural land (Chace \& Walsh, 2006; Savard et al., 2000; Zalewski, 1994; DeGraaf et al., 1991).

Urban development faces greater challenges and plays an important role in protection and conservation of urban biodiversity. Awareness of conservation is important as cities grow rapidly to fulfill physical and social needs. Thus, the aim of this paper is to present the pattern of urban wildlife and its habitat characteristics in urban parks in the City of Kuala Lumpur, Malaysia.

\section{Theoretical Background}

Recently, landscape and urban green space planning has been gaining prominence in urban planning, design and development (Chiesura, 2004; Balram \& Dragicevic, 2005). According to Balram and Dragicevic (2005) limited literature exists in environment and planning that discuss the importance of landscape and urban green space planning.

Urban green space and biodiversity are crucial to sustainable cities because it involves social, economic and environmental issues, and if managed properly result in ecological benefits for its inhabitants. Professionals and citizens are aware of the value of urban green space and its capacity to promote of social integration, community development and environmental protection (Swanwick et al., 2003; Balram \& Dragicevic, 2005; Chiesura, 2004). Balram and Dragicevic (2005, p. 149) argue that "a desire to improve the quality of community life; environmental protection; participation in decisions that will affect their lives; concerns for social conditions; need for satisfaction with their surroundings; pride in their inter-generational legacy and mistrust of representation made by elected official".

"Human dimension" involves the relationship between social information and biodiversity information. Usually it is about understanding of values, attitudes, knowledge and behaviors (Miller \& McGee, 2000). According to Miller and McGee (2000) the most comprehensive study investigated human relation with wildlife was done by Stephen Kellert in 1970s.

In many countries there is little awareness about conservation of environment and biodiversity (Niemelä, 1999; Miller \& McGee, 2000) and there is little agreement of this concept among built environment professionals (Brown \& Grant, 2005). This is also supported by Balram and Dragicevic (2005, p. 147) who state that the "Attitude influence behavior towards urban green space. But determining attitudes towards urban green space is not well operationalized in urban planning research". There are very few studies on urban parks and its biodiversity especially by the built environments professionals. Most of the studies are focused towards wildlife managers and concentrate on reserved forest or conservation areas (Miller \& McGee, 2000). It is therefore important to understand the relationship between biodiversity and built environment. 
Urban green space planning has been implemented to fulfill predominantly the social needs of people and little consideration given to environmental aspects such as wildlife and biodiversity, woodlands and wetlands. Thus, fragmentation and isolated patches of green space that exist in cities is the result of disjointed land use planning that affect urban biodiversity population. Because of low priority given to improve green space many towns have gradually reduced their budget for green space maintenance (Chiesura, 2004; Balram \& Dragicevic, 2005) or virtually ignored the importance of green space planning. Thus, it is important to investigate the huge demand for green spaces including peoples' attitudes towards urban green space and urban biodiversity for more responsible city planning. In Malaysia there is very limited research in field of biodiversity such as wildlife.

In most of the large cities in developing countries urban green space is declining because of the pressures of rapid urbanization, residential and commercial developments. If this trend continues it will invariably affect the health and sustainability of the urban environment and lead to long-term damage and loss of natural habitat, fragmentation and disturbance (Pauleit, 2003; Brown \& Grant, 2005; Tratalos et al., 2007; McKinney, 2008). The decline in the amount of urban green space has led to many problems such as floods, air and noise pollution and social and health issues. Therefore, it is important to study green space planning and develop suitable strategies that will lead to the creation and conservation of healthy living environments.

Despite the focus on mega fauna, there are less concern and effective management of less popular wildlife species especially in urban areas. There is little research on the impact and relationship of urbanization on urban wildlife. Thus it is important to understand human ecosystem in relation to urban vegetation and urban wildlife. Species richness and density can be associated with the quality of urban environment. Thus, many studies have studied birds as a biological indicator. Most of the studies conclude that urban centers have recorded lower species richness and it was increasing towards suburban areas to the agricultural, rural and natural land (Chace \& Walsh, 2006; Savard et al., 2000; Zalewski, 1994; DeGraaf et al., 1991).

City managers face greater challenges and play an important role in protection and conservation of urban biodiversity. Awareness of conservation is important as cities grow rapidly towards meeting physical and social needs.

\section{Methodology}

A case study method was adopted to present the current pattern of urban wildlife and its habitat characteristics in urban parks in the city of Kuala Lumpur, Malaysia. Kuala Lumpur aims to promote and improve the quality of its living environment and develop a sustainable approach for the development of urban green space. Therefore it was an appropriate case study to study the pattern of biodiversity especially wildlife and how it relates to planning and development.

An urban wildlife observation survey was conducted between November 2009 and January 2010. The objective of the survey was to identify the abundance of birds, mammals and reptile species in the urban parks of Kuala Lumpur. The survey captured species name, number of species, habitat, observation time and date, and remarks for reference notes.

The survey used transects line for observation and species. This approach used the "Distance Sampling Method" introduced by Buckland et al. (1993). The transect lines consist of 1 to 4 lines depending on the size of the urban parks. Each of the transect lines was recorded twice a day; in the early morning between 7.30am to 10.00am and in the evening from $4.00 \mathrm{pm}$ until $6.00 \mathrm{pm}$. Observation was used to identify the species within 30 meters distance perpendicular to the transect line. Identified species were validated with the species database provided by the Department of Wildlife and National Parks (DWNP). To conduct observation survey urban parks in Kuala Lumpur were selected as case studies. Following section will describe the selected case studies.

The research was conducted in selected urban parks in Kuala Lumpur. There are nine urban parks consisting of three categories of urban parks viz. city parks, district parks and neighborhood parks. Table 1 depicts size and hierarchy of open spaces and Figure 1 shows the locations of the parks. The hierarchy of the open space is adopted from GP005-A 9th edition, Planning Guideline for Open Space and Recreation, Department of Urban and Rural Planning, Ministry of Housing and Local Authorities (2013). 
Table 1. Size and hierarchy of urban parks

\begin{tabular}{|c|c|c|c|}
\hline Name & Location/District & $\begin{array}{c}\text { Size } \\
\text { (Hectare) }\end{array}$ & Hierarchy \\
\hline $\begin{array}{l}\text { Perdana Lake } \\
\text { Garden }\end{array}$ & $\mathrm{CBD}$ & 70 & City park \\
\hline $\begin{array}{c}\text { Kepong } \\
\text { Metropolitan Parks }\end{array}$ & North. Sentul - Manjalara & 127 & District park \\
\hline $\begin{array}{l}\text { Batu Metropolitan } \\
\text { Park }\end{array}$ & North. Sentul - Manjalara & 24 & District park \\
\hline $\begin{array}{l}\text { Titiwangsa Lake } \\
\text { Garden }\end{array}$ & West. Wangsa Maju - Maluri & 46 & District park \\
\hline Pudu Lake Garden & $\begin{array}{l}\text { South West. Bandar Tun Razak- } \\
\text { Sg Besi }\end{array}$ & 26 & District park \\
\hline $\begin{array}{l}\text { Permaisuri Lake } \\
\text { Garden }\end{array}$ & $\begin{array}{l}\text { South West. Bandar Tun Razak } \\
\text { - Sg Besi }\end{array}$ & 50 & District park \\
\hline Bukit Jalil Park & Southern. Bukit Jalil -Seputeh & 22 & District park \\
\hline $\begin{array}{c}\text { Datuk Keramat Lake } \\
\text { Garden }\end{array}$ & West. Wangsa Maju - Maluri & 6 & Neighborhood park \\
\hline $\begin{array}{l}\text { Manjalara Lake } \\
\text { Garden }\end{array}$ & North. Sentul - Manjalara & 10.6 & Neighborhood park \\
\hline
\end{tabular}

Source: Baharuddin et al., 2010. 


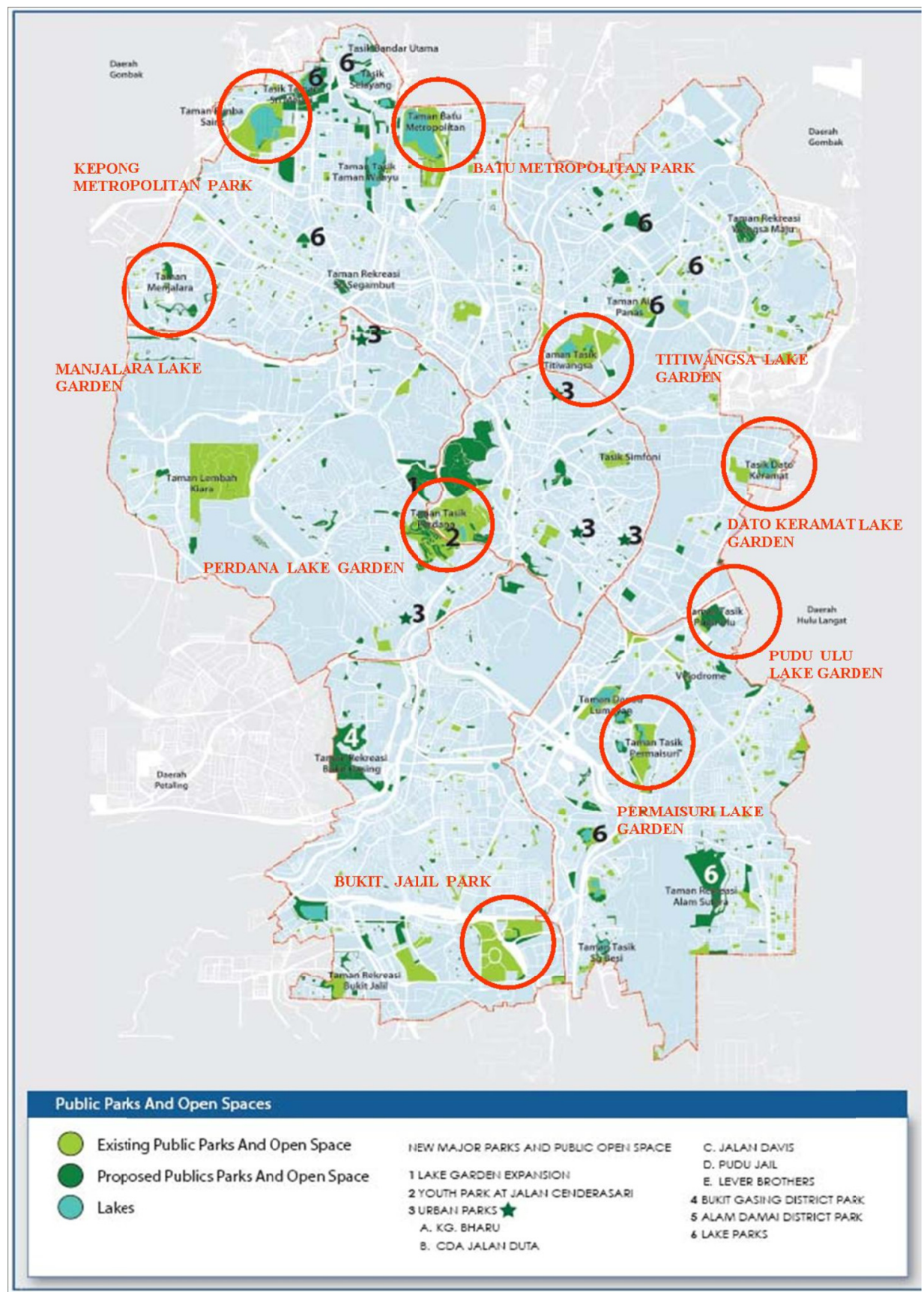

Figure 1. Location of the nine urban parks in Kuala Lumpur

Source: CHKL, 2004.

\section{Results}

The results of the observation survey for each case study parks are presented in following section.

\subsection{Titiwangsa Lake Garden}

Titiwangsa Lake Garden is located in the west of the City of Kuala Lumpur and is zoned as a district of Sentul Manjalara. The park is adjacent to the city centre and is very popular among urban dwellers. The lake garden is categorized as a District Park and it is about 46 hectares surrounded by strategic tourist attractions such as the National Library, Art Museum and National Theatre (Istana Budaya).

The survey found that most of the identified wildlife were bird species. There were not many taxonomy, for example two reptile species namely Varanus salvator (water lizards/biawak) (n=5) and Trachemy scripta 
elegans (Kura-kura telinga merah) $(\mathrm{n}=3)$ were found. Only one species of small mammals Scotophilus Kuhlii (Bat/Kelawar rumah) was found during the observation survey.

The most dominant bird species was Passer montanus (Eurasian Tree Sparrow/Ciak Rumah) about 30\%: trail A $(n=27)$, trail $B(n=23)$ and trail $C(n=15)$. The species was commonly found on the open area such as open grass, around the structures and was usually found in groups. Figure 2 depicts bird species found in Titiwangsa Lake Garden.

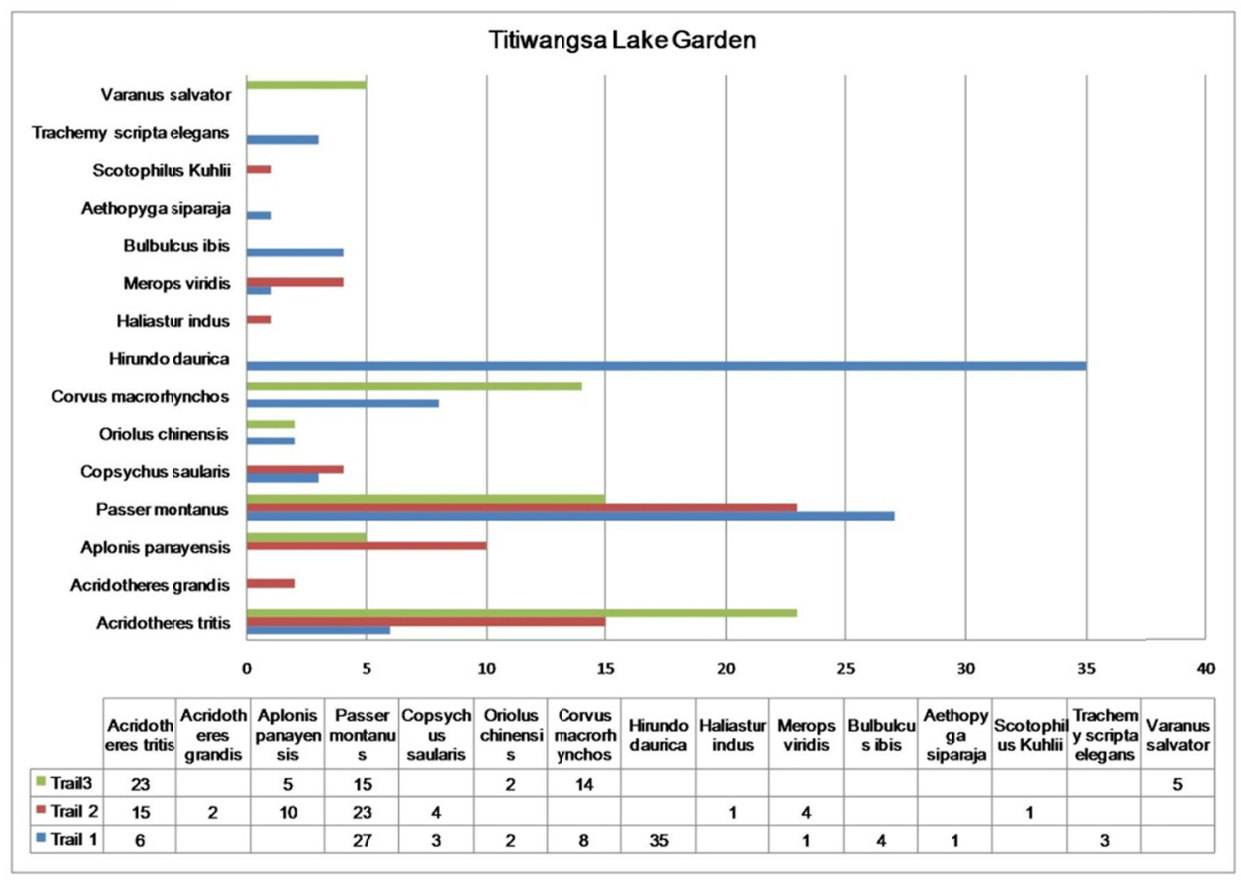

Figure 2. Urban wildlife distribution at Titiwangsa Lake Garden

The second-most frequently found bird species was Acridotheres tritis (Common Myna/Tiung gembala kerbau) (20\%). Trail B and C were favorite areas for the common myna. The next most frequent was Hirundo rustica (Barn swallow/Sualo api) with $16 \%$. The species was mostly found in trail A $(n=35)$ because the trail was an open area with a water body and grass areas. This was followed by Corvus macrorhynchos (Crow/Gagak paruh besar) with $10 \%$, and Aplonis panayensis (Asian glossy starling/Perling mata merah) (7\%): usually these species were also found in groups.

Other species were less in numbers as perhaps the species were not in large groups. For example, Copsychus saularis (magpie robin/murai kampong) (3\%) were found either in pairs or singly. Moreover, it was difficult to establish the species associated with water and water edges, such as Bulbucus ibis (cattle egret/Bangau putih) $(2 \%)$.

\subsection{Permaisuri Lake Garden}

Permaisuri Lake Garden provides recreational space and a "green lung" for people in Cheras, the district of Bandar Tun Razak - Sg. Besi. The lake is categorized as a District Park of 50 hectares in size. The Permaisuri Lake Garden has been divided into three trails for the observation survey. Ten wildlife species were identified at Permaisuri Lake Garden including eight bird and two reptile species. 


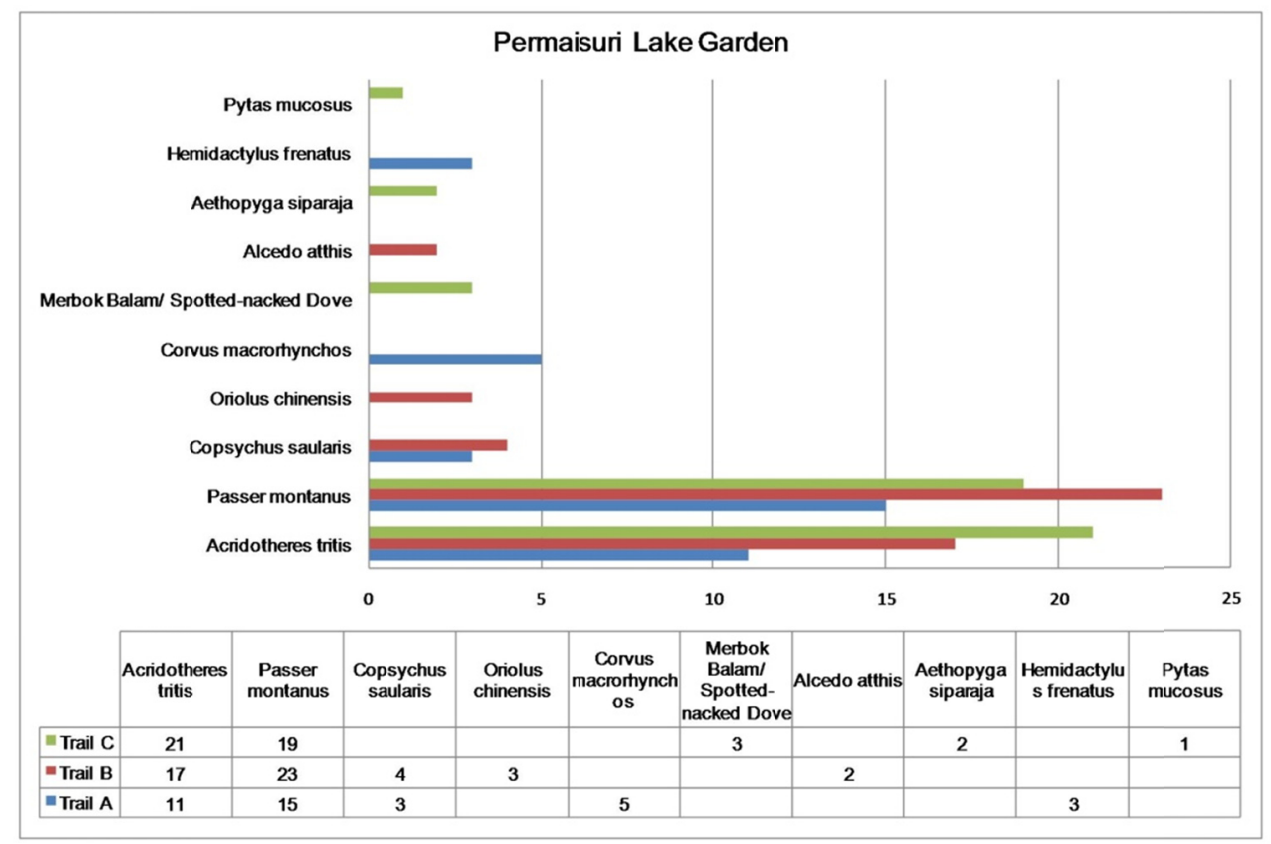

Figure 3. Urban wildlife distribution at Permaisuri Lake Garden

Passer montanus (Eurasian Tree Sparrow/Caiak Rumah) were found to be the dominant bird species in the lake garden with $43 \%$. The species was found in larger numbers at trail $B(n=23)$, Trail $C(n=19)$ and Trail A ( $n=15)$. The second-most dominant species was Acridotheres tritis (Common Myna/Tiung gembala kerbau) with 37\%. Numbers identified during the observation were: at trail $C(n=21)$, trail $B(n=17)$ and trail A with $(n=11)$.

Copsychus saularis (magpie robin/murai kampong) was found in trail $\mathrm{B}(\mathrm{n}=4)$ and trail $\mathrm{A}(\mathrm{n}=3)$. Corvus macrorhynchos (Crow/Gagak paruh besar) appear only at trail A $(\mathrm{n}=5)$. Protected bird species such as Oriolus chinensis (Black Naped Oriole/Dendang Selayang) $(\mathrm{n}=3)$ and Merbok Balam/Spotted-necked Dove ( $\mathrm{n}=3$ ), Alcedo atthis (Common Kingfisher/Pekaka Cit Cit) $(\mathrm{n}=2)$ and Aethopyga siparaja (Kelicap) $(\mathrm{n}=2)$ were found during the survey.

\subsection{Bukit Jalil Park}

The park and Bukit Jalil development were established as a sports centre for the Commonwealth Games in 1998. The park provides recreation facilities and many attractions such as a man-made lake and theme gardens. The observation survey identified eight bird, one mammal and two reptile species. Among the eight bird species were two species which were omnivorous, two frugivorous, two insectivorous, one granivorous and one nectarous. 


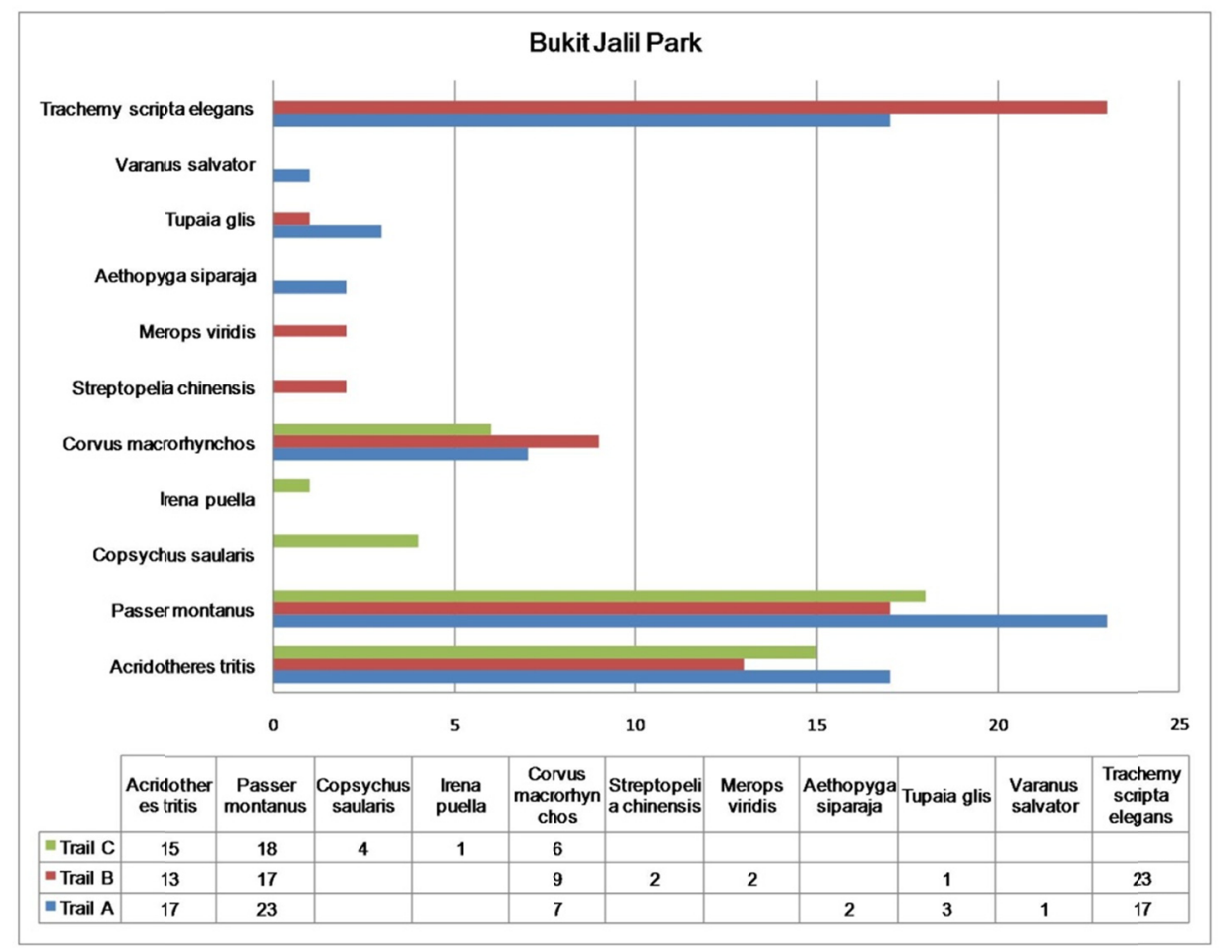

Figure 4. Urban wildlife distribution at Bukit Jalil Park

Three dominant bird species usually found in the park were Passer montanus (Eurasian Tree Sparrow/Ciak Rumah) 32\%, Acridotheres tritis (Common Myna/Tiung gembala kerbau) 25\% and reptiles Trachemyscripta elegans (Terrapin/Kura-kura Telinga merah) 22\%.

Passer montanus which was granivorous (feeding on grain and seed) was frequently found around the parks (at Trails A, B and C). This species is not listed in the Act 76/72 (Protection of Wild Life Act 1972) but is listed in the IUCN Red List. Acridotheres tritis and Corvus macrorhynchos are omnivorous and also can easily be found around the parks. Both birds are not listed in Act 76/72. Corvus macrorhynchos has been listed as a least threatened species by IUCN and Acridotheres tritis was listed among the 100 worst invasive species in the world.

All wildlife species found at Bukit Jalil Park were among the least threatened species in the IUCN Red List. However, four species listed in the Act 76/72 as protected wildlife were present: Irena puella (fairy blue bird/Dendang gajah) $(\mathrm{n}=1)$, Merops viridis (bee-eater/Berek-berek tadah hujan $(\mathrm{n}=2)$, Aethopyga siparaja (sunbird/kelicap sepah Raja) $(\mathrm{n}=2)$ and small mammals Tupaia glis (Treeshrew/ squirrel) $(\mathrm{n}=4)$. These species were found at trails $\mathrm{A}$ and $\mathrm{B}$ which have more vegetation and flowering plants.

Trachemyscripta elegans (Terrapin/Kura-kura Telinga merah) has been introduced as aquatic wildlife and it was the main attraction for tourists and visitors to the park. Visitors appreciate and feed the wildlife.

\subsection{Manjalara Lake Garden}

Manjalara Lake Garden is located in the west of the City of Kuala Lumpur. The park is surrounded by residential and commercial areas and it functions as the neighborhood park for the local community. Only eight bird species were identified during the observation survey. There were no signs of reptiles and mammals in and around the park. This is because the park was recently developed and hence has less mature vegetation that could provide habitat and foods. 


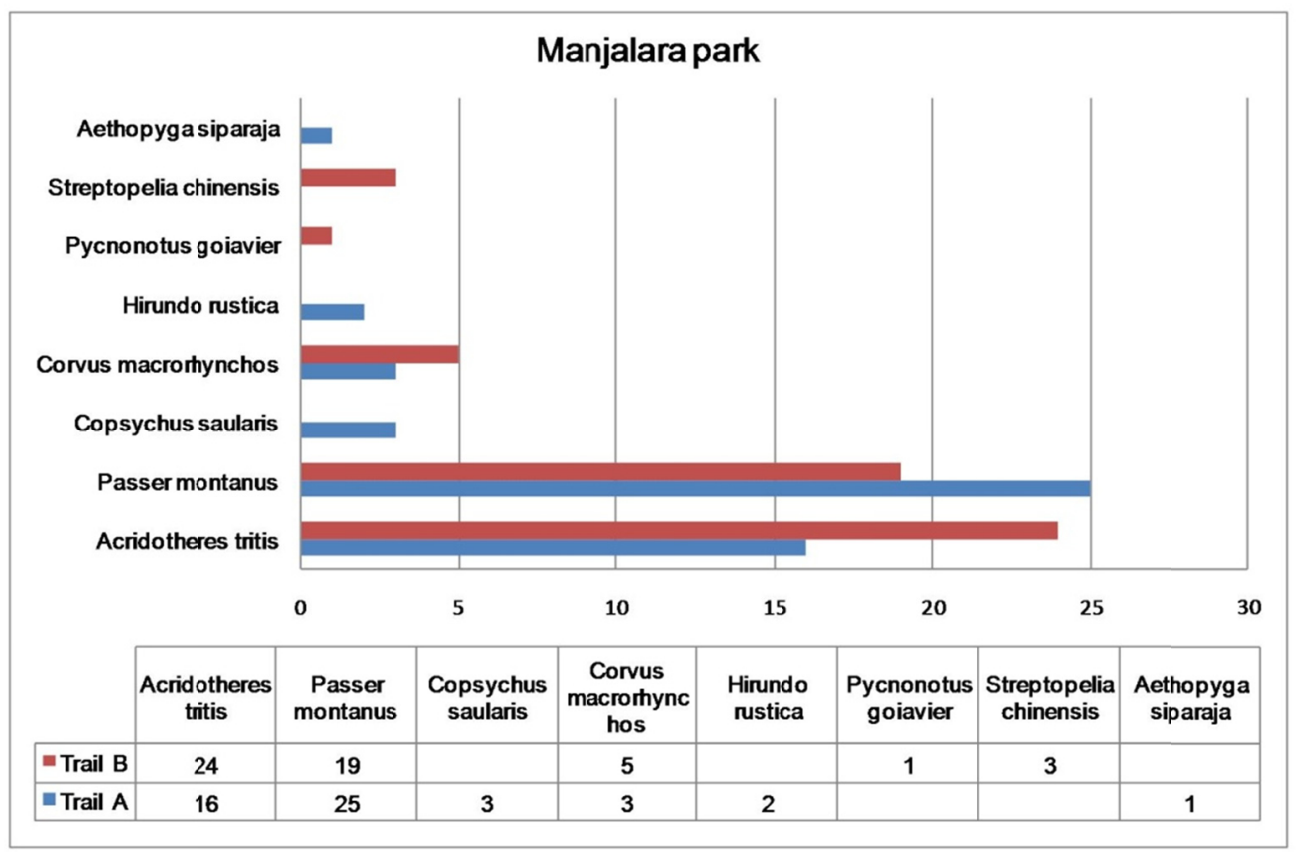

Figure 5. Urban wildlife distribution at Manjalara Park

Three protected species namely Hinduro rustica (Barn swallow/soalo api) (n=2), Pycnonotus goiavier (Yellow vented bulbul/merbah kapur) ( $\mathrm{n}=1)$ and Aethopyga siparaja (sunbird/kelicap sepah Raja) $(\mathrm{n}=1)$ were present in the park. There were other species that were not listed in the Act 76/72. Moreover, all species found in the park were listed as least threatened species in the IUCN Red List. Passer montanus (Eurasian Tree Sparrow/Ciak Rumah) 32\%, Acridotheres tritis (Common Myna/Tiung gembala kerbau) 25\% and Corvus macrorhynchos (Crow/Gagak paruh besar) with $8 \%$ were the most identified bird species.

\subsection{Perdana Lake Garden}

Established in 18th century as a green lung for Kuala Lumpur, Perdana Lake Garden is a famous tourist destination. It is divided into sub-gardens such as Hibiscus Garden, bird parks, national monuments and Lake Garden. Figure 6 depicts wildlife species found in the garden. Perdana Lake Garden is home to more species compared to the other parks. This is because the park has more mature vegetation which provides good habitat. Eighteen (18) species of wildlife were found during the observation study including nine protected species. Similar numbers of species were observed in all trails: trail no $1(n=11)$, trail $2(n=11)$ and trail $3(n=10)$. 


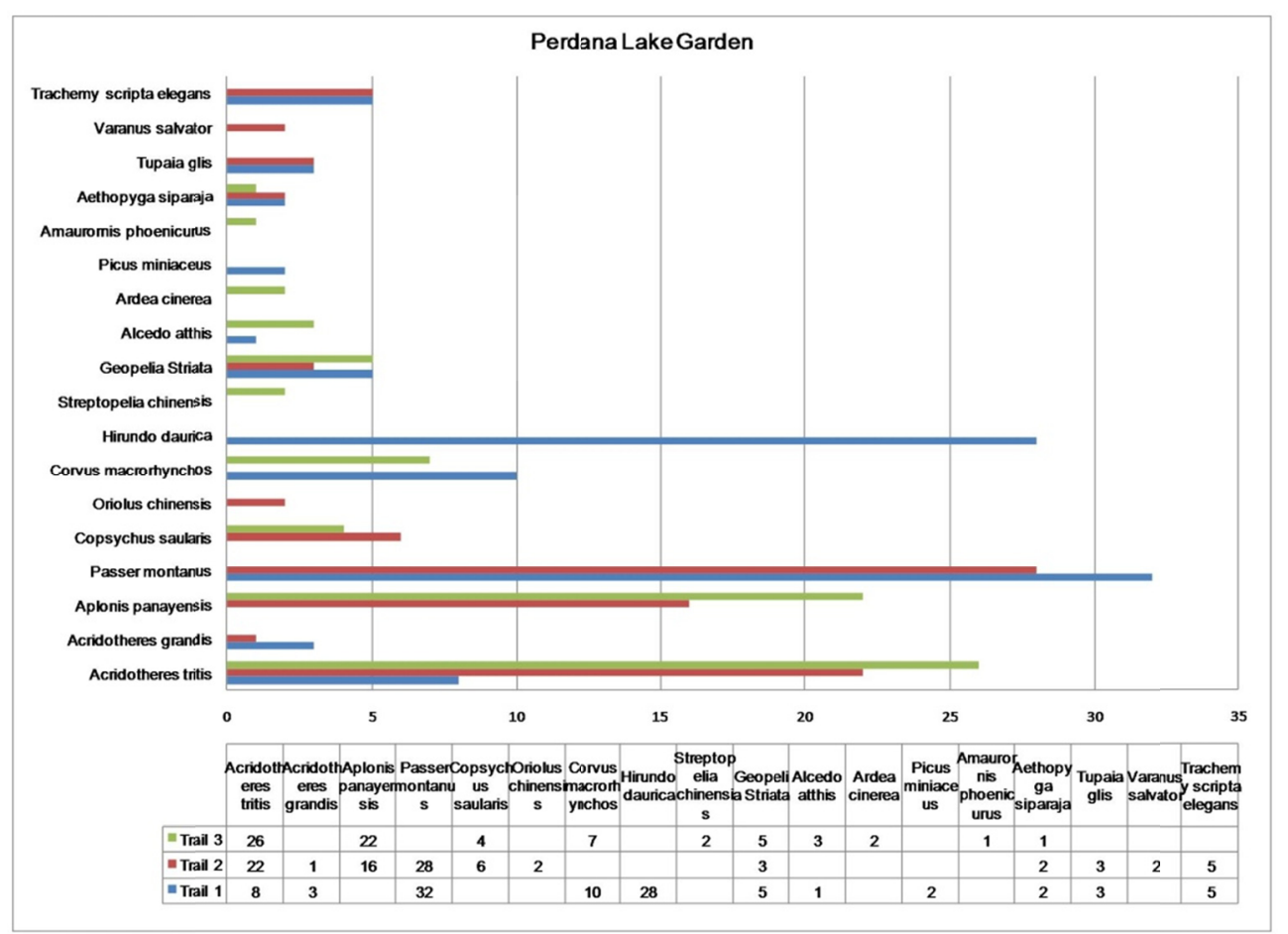

Figure 6. Urban wildlife distribution at Perdana Lake Garden

Four species were commonly found in all parks in Kuala Lumpur. There were some rare species such as Aplonis panayensis (Asian Glossy Starling/Perling Mata Merah) (n=38), Picus miniaceus (Banded Woodpecker/Belatuk Merah) $(\mathrm{n}=2)$ and Ardea cinerea (Grey Heron/Pucung Seriap) $(\mathrm{n}=2)$. Despite having many bird species and richness of habitats, the Perdana Lake Garden also recorded low numbers of mammal and reptile species.

\subsection{Kepong Metropolitan Park}

Historically this was mining land which has been developed as a district park with modern facilities. Activities involving playing with kites are the main attraction among local citizens. Figure 7 depicts wildlife species found in the park. The survey recorded 13 bird species in Kepong Metropolitan Park. Eight species found in the park were protected species and two species found in this park were rarely found at other parks. They are Merops Philippinus (Blue tailed Bee-eater/ Berek-berek Carik Dada) ( $\mathrm{n}=3$ ) and Bulbucus ibis (cattle egret/Bangau putih) $(\mathrm{n}=2)$. There were no signs of mammals and reptiles. 


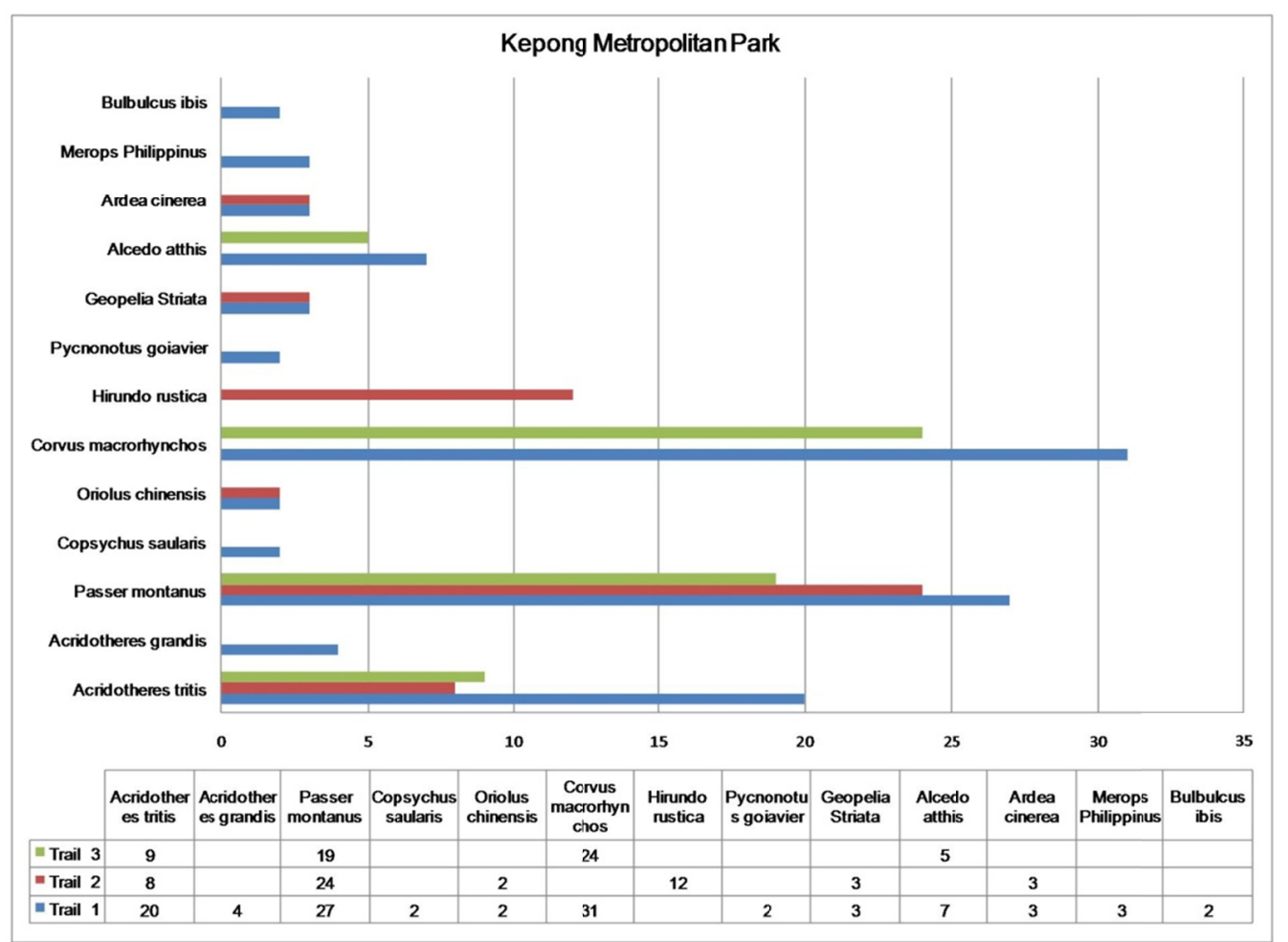

Figure 7. Urban wildlife distribution at Kepong Metropolitan Park

Corvus macrorhynchos (Crow/Gagak paruh besar) $(\mathrm{n}=55)$ were found in higher numbers at Kepong Metropolitan Park compared to other parks in Kuala Lumpur. This was due to the site being close to the converted waste landfill area which has been developed into a green area.

\subsection{Batu Metropolitan Park}

Batu Metropolitan Park is located in the northern side of the City of Kuala Lumpur. The park is spread over 24 hectares with a man-made lake, water fountain, children's playground, sports centre and is adjacent to a mining area. However, the park was less accessible to the public due to limited numbers of entrances to the park and its location being isolated as it is surrounded by a housing area. Figure 8 depicts wildlife species found in the park. The survey identified 13 bird species and two reptile species. Six bird species found in the park were protected species and another three species were found which are rarely found at other parks such as Lonchura maja (White headed mania/Pipit Uban) (n=23), Haliastur indus (Brahminy Kite/Lang Merah) $(\mathrm{n}=2)$ and reptiles Bronchocela cristatella (Green Crested Lizard/Sesumpah). 


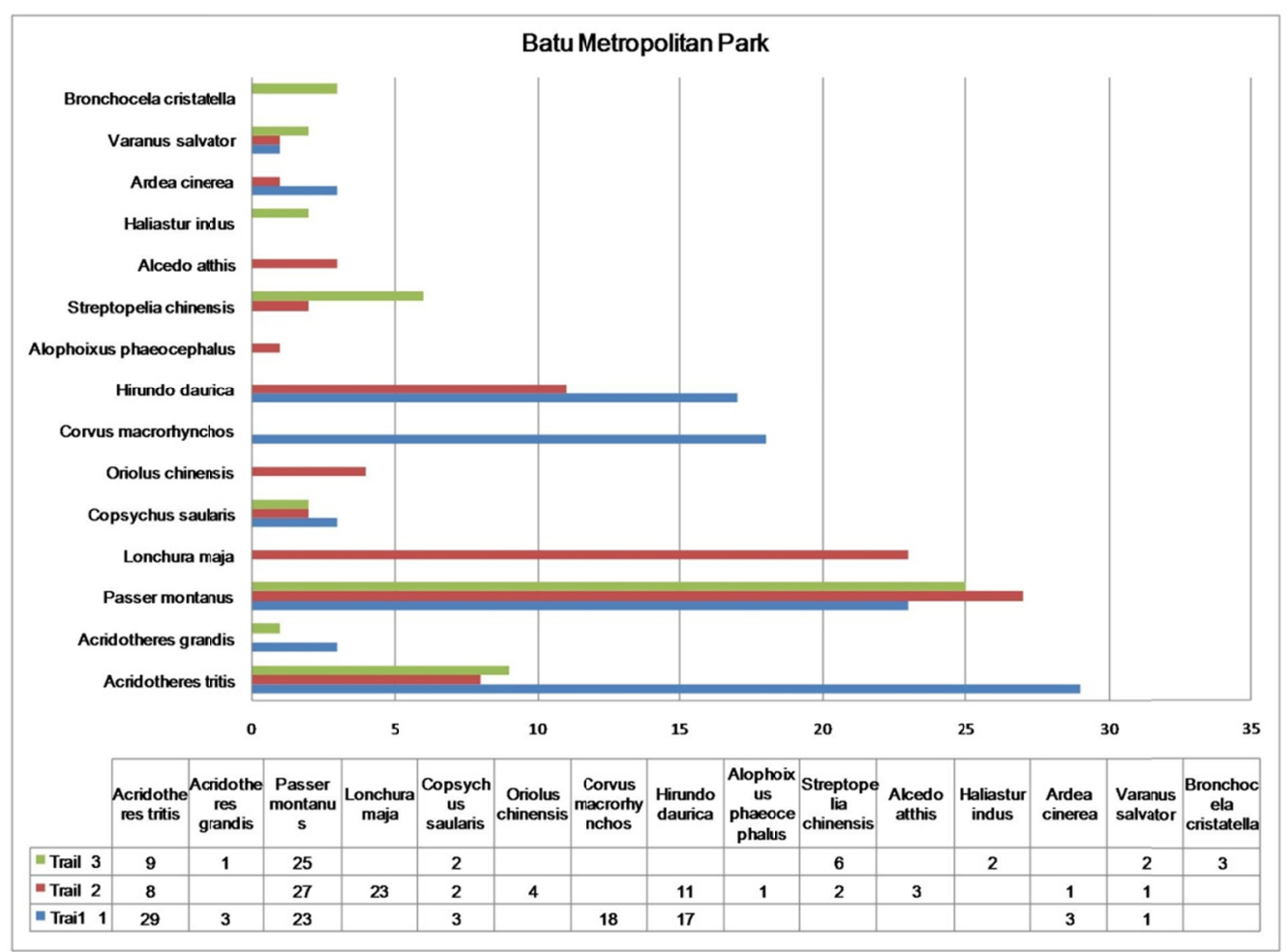

Figure 8. Urban wildlife distribution at Batu Metropolitan Park

Lonchura maja (White headed mania/Pipit Uban) was found at trail no 2. The trail has natural settings of water edges with plants such as water grass and water lily, and thus it is a suitable habitat for the Lonchura spp. Haliastur Indus and Bronchocela cristatella were found at trail no 3 which is more shaded and has more mature trees.

\subsection{Pudu Ulu Park}

This new park for Cheras was opened to the public in 2007 and it was expected to serve residents in the surrounding neighborhood. It has been gazetted as a park by City Hall. Figure 9 depicts wildlife species found in the park. The survey identified 10 bird and two reptile species at Pudu Ulu Park. The study found four protected species and these were commonly found at other parks in Kuala Lumpur. However, at Pudu Ulu Park the numbers of protected birds was quite small except for Hirundo rustica (Barn swallow) which is usually found in groups. This is because the park has less vegetation. Thus, common species such as Passer montanus, Acridotheres tritis, Corvus macrorhynchos and Hirundo rustica are dominant. 


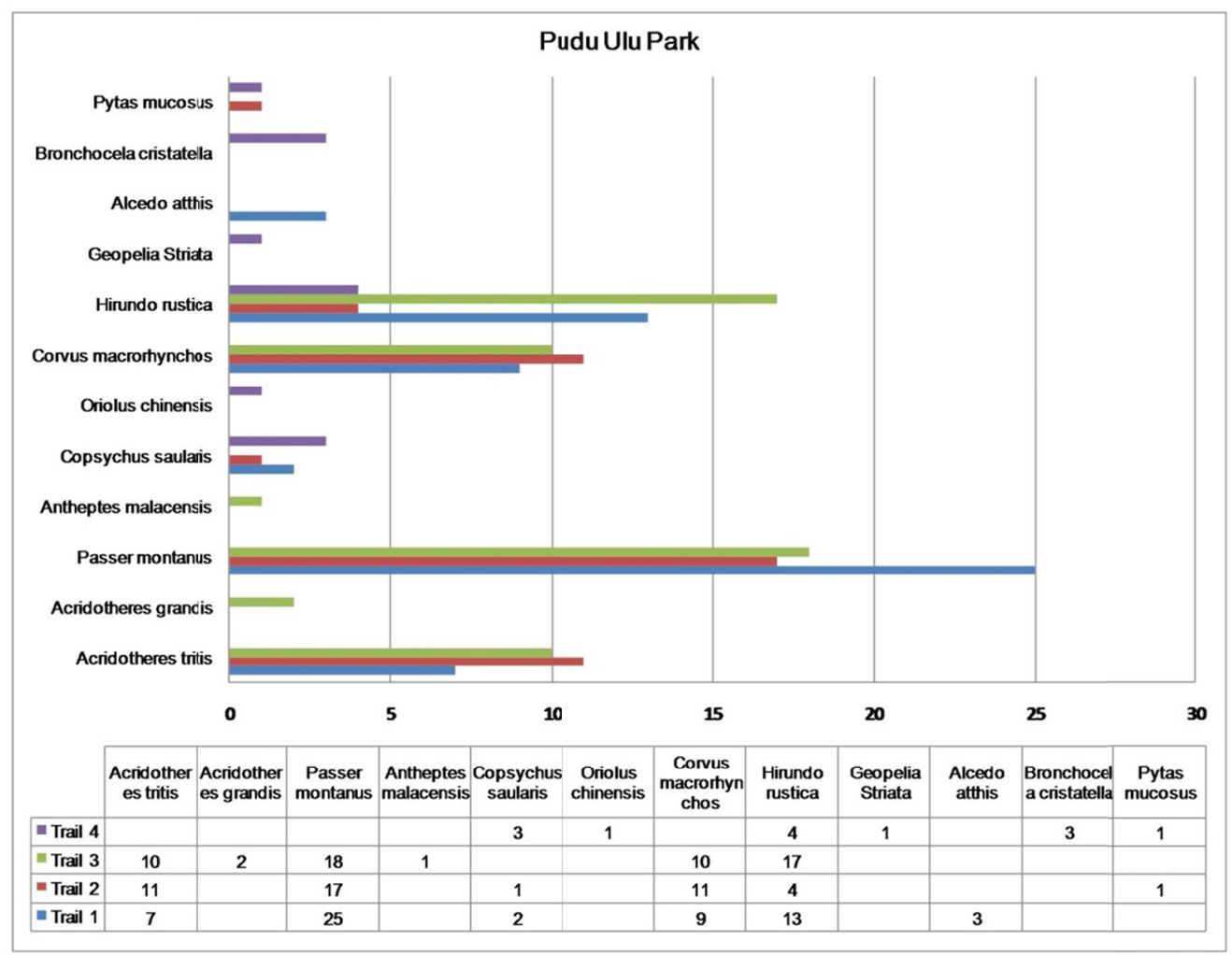

Figure 9. Urban wildlife distribution at Pudu Ulu Park

During the survey some species of dangerous snakes such as Pytas Mucosus were found in the park and these are dangerous to visitors especially children. Bronchocela cristatella (Green Crested Lizard/Sesumpah) $(\mathrm{n}=3)$ is another reptile species found at Pudu Ulu Park.

\subsection{Datuk Keramat Lake Garden}

Datuk Keramat Lake Garden provides recreational space for the surrounding area especially to people in Datuk Keramat and Wangsa Maju. The park was accessible and easily connected by the Light Rail Transit (Putra LRT) and by car. Figure 10 depicts the wildlife species observed in the park.

Eight species of birds were found in the park. Among them, four are protected species by the Act 76/72. They are Oriolus chinensis (Dendang Selayang/Black Naped Oriole) $(\mathrm{n}=1)$, Hirundo rustica (Sualo api/Barn Swallow) $(\mathrm{n}=18)$, Geopelia Striata (Zebra Peaceful Dove/Merbok Aman) $(\mathrm{n}=4)$ and Alcedo atthis (Pekaka Cit Cit/ Common Kingfisher) $(\mathrm{n}=1)$. 


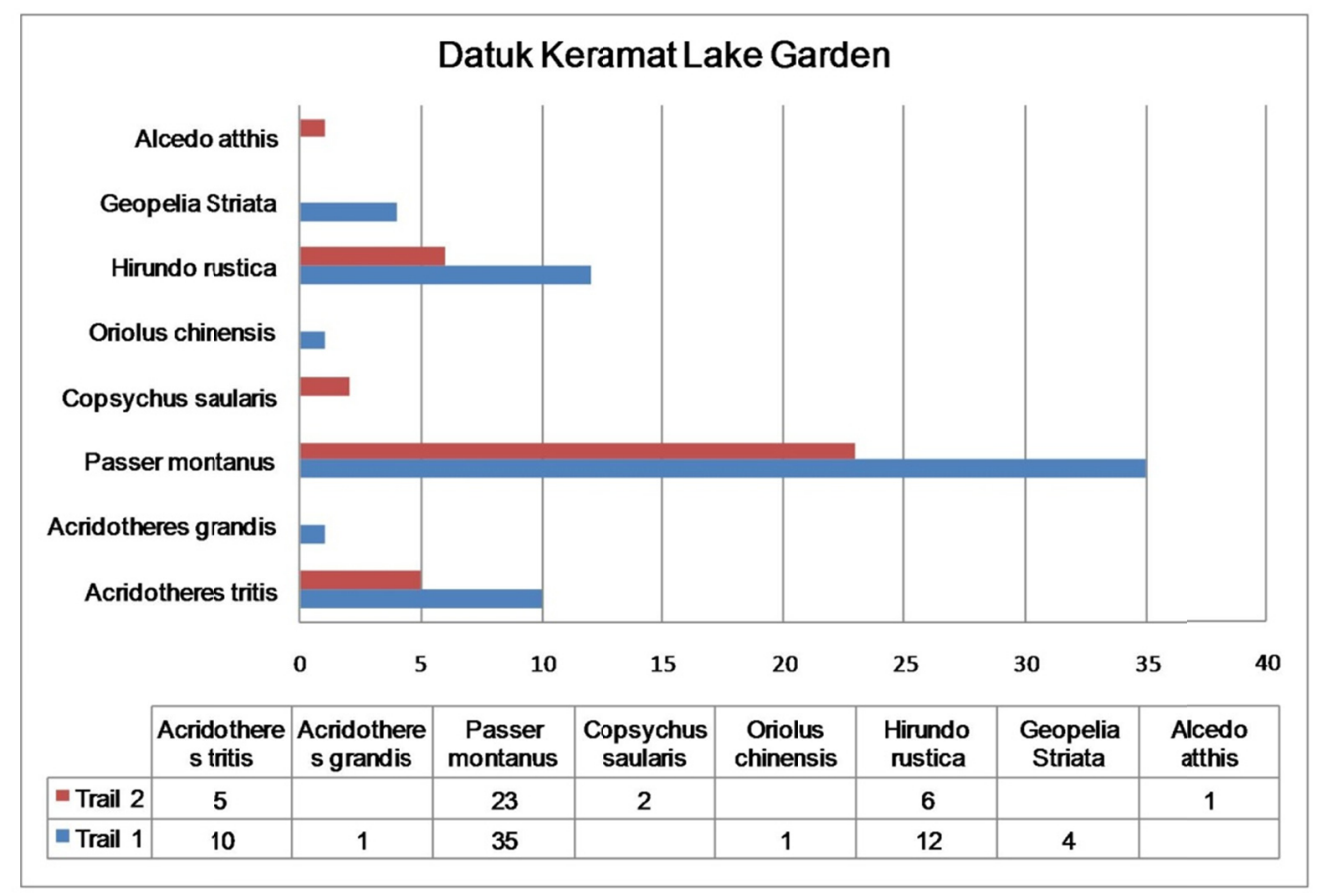

Figure 10. Urban wildlife distribution at Datuk Keramat Lake Garden

Passer montanus (Eurasian Tree Sparrow/Ciak Rumah) is the most dominant bird species (58\%) in this neighborhood park. Hirundo rustica (Sualo api/Barn Swallow) $18 \%$ and Acridotheres tritis (Common Myna/Tiung gembala kerbau) $15 \%$ are another two species easily found in the park and both are insectivores.

\section{Discussion and Conclusion}

The study found that two bird species are predominant in urban parks in Kuala Lumpur. They are Passer montanus (Eurasian Tree Sparrow/Caiak Rumah) $(\mathrm{n}=528)$ and Acridotheres tritis (Common Myna/Tiung gembala kerbau) $(n=360)$. The results also indicate that granivorous and omnivorous birds are most tolerant in the urban area. Yorke (1984) in his study of the avian community in rubber plantations and suburban areas at Bukit Kiara, Kuala Lumpur found that Passer montanus (Eurasian Tree Sparrow/Caiak Rumah) was the most abundant species in the suburban area and its number gradually declined in agricultural land immediately outside the city.

Omnivorous birds such as Carvus are relatively common in urban parks. This species could be considered as a threat to other native species and disturbs other habitats. The area will be unpleasant when the species is in abundance. Despite having large numbers of homogeneous bird species, Kuala Lumpur is facing an acute decline in wildlife. For example, the survey found that insectivorous species such as Copsychus saularis and Hirundo rustica are among the frequently found bird species in parks. However, Yorke (1984) has listed 14 insectivorous species found in suburban areas and outskirts of the rubber plantations of Bukit Kiara Kuala Lumpur. However in this study only three insectivorous species were found in and around urban parks.

Significantly low numbers of frugivorous and nectarous species were recorded in all urban parks in Kuala Lumpur. It could be argued that urban parks in Kuala Lumpur are dominated by ornamental plant species and there are fewer plants that provide food and flowers.

Another study recorded 23 species of birds in the Perdana Lake Garden (Mohamad et al., 2008). In comparison, only 15 species of birds were observed in this study. Many species such as Pycnonotus flavescens (Merbah Kening Putih), Pycnonotus brunneusides (Merbah Mata Merah) and Megalaima farrlesii (Tekur gunung/Red crowned belbet) were not found. Thus, urban wildlife records and management are vital to the management of urban parks to ensure healthy numbers of wildlife. The regulation and enforcement of urban wildlife conservation is critical to urban ecology and sustainability.

Urban parks in Kuala Lumpur have huge benefits. The study presents an empirical survey of wildlife in Kuala Lumpur and argues a strong case for the protection and better management of urban parks for their role in providing habitats and protecting the habitat from urban development. More native vegetation can encourage 
wildlife in urban parks and provide shelter and food. It is also suggested that the urban green space in Kuala Lumpur be protected by enforcing the existing legislation governing the protection of wildlife and no new legislation is required.

\section{References}

Baharuddin, Z. M., Sivam, A., Karuppannan, S., \& Daniels, C. (2009). Role and Perception of Green Spaces: Attitudes Towards Urban Wildlife in Kuala Lumpur and Adelaide, Paper presented at the International Symposium on Construction in Developing Economies: Commonalities Among Diversities, 5-7 October, University of Sains Malaysia, Penang, Malaysia.

Baharuddin, Z. M., Sivam, A., Karuppannan, S., \& Daniels, C. (2010). Urban green space: Stakeholders' and visitors' perception in Kuala Lumpur Malaysia, presented at the Healthy City Conference: Making Cities Liveable, 11-13 July, Brisbane, Australia.

Balram, S., \& Dragicevic, S. (2005). Attitudes toward urban green spaces: integrating a questionnaire survey and collaborative GIS techniques to improve attitude measurements. Landscape and Urban Planning, 71(2-4), 147-162.

Brown, C., \& Grant, M. (2005). Biodiversity and Human Health: What role for nature in healthy urban planning? Built Environment, 31(4), 326-338. http://dx.doi.org/10.2148/benv.2005.31.4.326

Chace, J. F., \& Walsh, J. J. (2006). Urban effects on native avifauna: A review. Landscape and Urban Planning, 74(1), 46-69. http://dx.doi.org/10.1016/j.landurbplan.2004.08.007

Chiesura, A. (2004). The role of urban parks for the sustainable city, Landscape and Urban Planning, 68(1), 129-138. http://dx.doi.org/10.1016/j.landurbplan.2003.08.003

CHKL. (2004). Kuala Lumpur Structure Plan 2020. Kuala Lumpur City Hall. Retrieved from http://www.dbkl.gov.my/pskl2020/english/index.htm

DeGraaf, R. M., Geis, A. D., \& Healy, P. A. (1991). Bird population and habitat surveys in urban areas. Landscape and Urban Planning, 21(3), 181-188. http://dx.doi.org/10.1016/0169-2046(91)90017-G

IUCN. (2010). International Union for Conservation of Nature, Gland, Switzerland.

Loss, S. R., Ruiz, M. O., \& Brawn, J. D. (2009). Relationships between avian diversity, neighborhood age, income, and environmental characteristics of an urban landscape. Biological Conservation, 142(11), 2578-2585. http://dx.doi.org/10.1016/j.biocon.2009.06.004

McKinney, M. L. (2008). Effect of urbanization on species richness: A review of plant and animals. Urban Ecosystem, 11(2), 161-176. http://dx.doi.org/10.1007/s11252-007-0045-4

Miller, K. K., \& McGee, T. K. (2000). Sex differences in values and knowledge of wildlife in Victoria, Australia. Human Dimensions of Wildlife, 5(2), 54-68. http://dx.doi.org/10.1080/10871200009359179

Ministry of Science. (1998). Malaysia's National Policy on Biological Diversity, Ministry of Science (pp. 1-27). Environment and Technology, Kuala Lumpur.

Mohamad, S. D. S., Samod, S., \& Mohammed, S. Z. (2008). Kepelbagaian spesis burung di taman Tasik Perdana, Kuala Lumpur. University Malaysia Sarawak, Kuching, Sarawak, Malaysia.

Niemelä, J. (1999). Is there a need for a theory of urban ecology? Urban Ecosystems, 3(1), 57-65. http://dx.doi.org/10.1023/A:1009595932440

Pauleit, S. (2003). Perspectives on urban greenspace in Europe. Built Environment, 29(2), 89-93. http://dx.doi.org/10.2148/benv.29.2.89.54470

Savard Jean-Pierre, L., Clergeau, P., \& Mennechez, G. (2000). Biodiversity concepts and urban ecosystems. Landscape and Urban Planning, 48(3-4), 131-142. http://dx.doi.org/10.1016/S0169-2046(00)00037-2

Swanwick, C., Dunnett, N., \& Woolley, H. (2003). Nature, Role and Value of Green Space in Towns and Cities: An Overview, Built Environment, 29(2), 94-106. http://dx.doi.org/10.2148/benv.29.2.94.54467

Tratalos, J., Fuller, R. A., Warren, P. H., Davies, R. G., \& Gaston, K. J. (2007). Urban form, biodiversity potential and ecosystem services. Landscape and Urban Planning, 83(4), 308-317. http://dx.doi.org/10.1016/j.landurbplan.2007.05.003

United Nations. (2010). International Year of Biodiversity. Retrieved from http://www.cbd.int/2010/welcome/ 
Yorke, C. D. (1984). Avian community structure in two modified Malaysian habitats. Biological Conservation, 29(4), 345-362. http://dx.doi.org/10.1016/0006-3207(84)90004-1

Zalewski, A. (1994). A comparative study of breeding bird populations and associated landscape character, Torun, Poland. Landscape and Urban Planning, 29(1), 31-41. http://dx.doi.org/10.1016/0169-2046(93)00153-G

\section{Copyrights}

Copyright for this article is retained by the author(s), with first publication rights granted to the journal.

This is an open-access article distributed under the terms and conditions of the Creative Commons Attribution license (http://creativecommons.org/licenses/by/3.0/). 